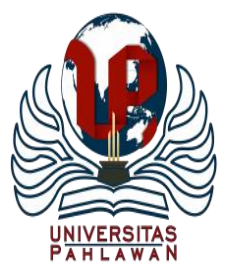

Edukatif : Jurnal Ilmu Pendidikan Volume 3 Nomor 2 Tahun 2021 Halm 589 - 597 EDUKATIF: JURNAL ILMU PENDIDIKAN

Research \& Learning in Education

https://edukatif.org/index.php/edukatif/index

\title{
Motivasi Belajar dan Respon Siswa terhadap Online Learning sebagai Strategi Pembelajaran di Masa Pandemi Covid-19
}

\author{
Firmansyah \\ Universitas Wahidiyah Kediri, Indonesia \\ E-mail : fugen.lbb@gmail.com
}

\begin{abstract}
Abstrak
Pembelajaran online yang diterapkan pemerintah sebagai upaya pencegahan dan pengendalian covid-19 memiliki kelebihan dan kekurangan yang berbeda antara suatu sekolah dengan sekolah yang lain. Penelitian ini bertujuan untuk mengetahui kelebihan dan kekurangan pembelajaran online di SMA Wahidiyah Kediri di masa pandemi covid-19 yang diperoleh langsung dari respon siswa serta pengaruhnya terhadap motivasi belajar. Rancangan penelitian yang digunakan adalah deskriptif kuantitatif. Instrumen pengukuran berupa angket respon pembelajaran online dan angket motivasi belajar yang disebarkan secara online menggunakan google formulir. Hasil penelitian dari respon siswa menunjukkan terdapat kelebihan dan kekurangan dalam pelaksanaan pembelajaran online di SMA Wahidiyah Kediri. Kelebihan dalam pembelajaran online yaitu: (1) pembelajaran dapat dilakukan dimana saja dan kapan saja; (2) melatih kemandirian belajar siswa; (3) pembelajaran lebih variatif; (4) sumber belajar yang lebih luas; dan (5) menghemat waktu, biaya, dan tenaga. Adapun kendala dalam pelaksanaan pembelajaran online yaitu: (1) koneksi atau jaringan internet yang lemah terutama pada daerah-dareah tertentu; (2) kebutuhan kuota internet yang besar; (3) kemampuan yang masih rendah dalam hal informasi dan teknologi (IT) baik dari guru maupun siswa; dan (4) desain model pembelajaran online yang belum tepat sehingga siswa kesulitan dalam memahami materi. Kekurangan dan kendala dalam pelaksanaan pembelajaran online lebih mendominasi sehinga motivasi belajar siswa menjadi rendah.
\end{abstract}

Kata Kunci: pembelajaran online, motivasi belajar, respon siswa, covid-19.

\begin{abstract}
Online learning implemented by the government as an effort to prevent and control Covid-19 has different advantages and disadvantages between one school and another. This study aims to determine the advantages and disadvantages of online learning at SMA Wahidiyah Kediri during the Covid-19 pandemic which were obtained directly from student responses and their effect on learning motivation. The research design used is descriptive quantitative. Measurement instruments are online learning response questionnaires and learning motivation questionnaires distributed online using google forms. The results of the research on student responses indicate that there are advantages and disadvantages in the implementation of online learning at SMA Wahidiyah Kediri. The advantages of online learning are: (1) learning can be done anywhere and anytime; (2) train students' learning independence; (3) more varied learning; (4) wider learning resources; and (5) saving time, cost and effort. The obstacles in the implementation of online learning are: (1) weak internet connections or networks, especially in certain areas; (2) large internet quota requirements; (3) low abilities in information and technology (IT) from both teachers and students; and (4) the design of the online learning model is not appropriate so that students have difficulty understanding the material. Weaknesses and constraints in the implementation of online learning dominate so that student learning motivation is low.
\end{abstract}

Keywords: online learning, learning motivation, student response, covid-19.

Copyright (c) 2021 Firmansyah

Corresponding author

Email : fugen.lbb@gmail.com

DOI : https://doi.org/10.31004/edukatif.v3i2.355

ISSN 2656-8063 (Media Cetak)

ISSN 2656-8071 (Media Online) 
590 Motivasi Belajar dan Respon Siswa terhadap Online Learning sebagai Strategi Pembelajaran di Masa Pandemi Covid-19- Firmansyah

DOI: https://doi.org/10.31004/edukatif.v3i2.355

\section{PENDAHULUAN}

Akhir tahun 2019 dunia mengalami musibah yaitu adanya wabah covid-19. Wabah covid-19 ini menyebar hampir ke seluruh penjuru dunia termasuk Indonesia. Penyebaran covid-19 sangat cepat, sehingga pemerintah menerapkan beberapa kebijakan sebagai upaya pencegahan penyebaran virus ini. Kebijakan pemerintah tertuang dalam Keputusan Menteri Kesehatan Republik Indonesia No. 382 Tahun 2020 tentang protokol kesehatan bagi masyarakat di tempat dan fasilitas umum dalam rangka pencegahan dan pengendalian corona virus disease 2019 (covid-19) diantaranya yaitu memakai masker, mencuci tangan menggunakan sabun, menjaga jarak, dan menghindari keramaian. Pemerintah juga membuat kebijakan untuk mengoptimalkan pelaksanaan protokol kesehatan seperti penutupan beberapa layanan publik, aktivitas pembelajaran di sekolah dihentikan berganti dengan belajar dari rumah, bekerja dari rumah (work from home), dan beribadah di rumah.

Kebijakan belajar dari rumah menyebabkan sistem pembelajaran yang semula tatap muka (face to face) di sekolah menjadi pembelajaran online atau daring dari rumah. Pembelajaran online merupakan kegiatan belajar mengajar antara guru dan siswa yang dapat dilakukan kapan dan dimana saja tanpa terbatas oleh jarak dan waktu. Pembelajaran online memungkinkan tidak adanya kontak fisik secara langsung antara guru dengan siswa ataupun sesama siswa sehingga dengan metode pembelajaran ini diharapkan dapat mengurangi penyebaran covid-19. Definisi lain pembelajaran online adalah berbagai teknologi seperti web, e-mail, groups discussion, application, konferensi audio dan video yang disampaikan melalui jaringan komputer untuk kegiatan pendidikan (Dhull \& Arora, 2017). Adapun menurut Fahy (2007) ciri-ciri pembelajaran online yaitu: (1) pembelajaran menggunakan media elektronik; (2) penggunaan software atau aplikasi dan jaringan internet; (3) pembelajaran jarak jauh; (4) peran media yang lebih dominan dalam pembelajaran; dan (5) pembelajaran online membutuhkan kemandirian siswa. Perangkat media berupa ponsel dan komputer dengan memori (penyimpanan) yang besar serta jaringan internet yang bagus sangat mempengaruhi kelancaran pelaksanaan pembelajaran online.

Pembelajaran online menjadi solusi dalam menjalankan pendidikan di masa pandemi covid-19 ini sehingga pendidikan tetap terlaksana dengan baik. Namun pembelajaran online bukanlah suatu sistem pembelajaran yang umum dilakukan di Indonesia dikarenakan selama ini pembelajaran dilakukan secara tatap muka (face to face). Guru dan siswa belum terbiasa dengan sistem pembelajaran online yang merupakan sistem pembelajaran yang baru diterapkan. Guru dituntut untuk dapat meyampaikan materi dengan baik sehingga siswa dapat memahami materi selayaknya pembelajaran di kelas. Prestasi belajar siswa juga diharapkan tidak menurun dan bahkan diharapkan dapat lebih baik, sehingga diperlukan beberapa persyaratan agar sistem pembelajaran online dapat terlaksana dengan lancar. Menurut Sun \& Chen, (2016) ada beberapa persyaratan yang diperlukan agar pembelajaran online terlaksana dengan baik, yaitu: (1) desain kelas atau model pembelajaran online yang baik; (2) interaksi atau komunikasi yang baik antara guru dan siswa; dan (3) perkembangan teknologi yang cepat. Perkembangan teknologi tentunya harus dibarengi dengan kemampuan guru dan siswa memanfaatkan teknologi tersebut dengan baik dalam pembelajaran.

Pembelajaran online sudah terlaksana hampir 1 tahun di Indonesia sebagai upaya pemerintah mencegah penyebaran covid-19. Guru dan siswa sudah mengalami pengalaman belajar secara online yang cukup banyak. Guru dituntut dan telah mendesain model pembelajaran online secara mandiri dengan tujuan agar siswa dapat memahami materi dengan baik. Evaluasi terhadap sistem pembelajaran online diperlukan untuk melihat keefektifan sistem pembelajaran tersebut. Melalui evaluasi pembelajaran akan ditemukan kekurangan atau kendala di dalam pelaksanaannya sehingga dapat dilakukan perbaikan untuk diperoleh sistem pembelajaran yang lebih baik (Oliver, 2000). Evaluasi diperlukan untuk melihat apakah pembelajaran online sudah dapat menggantikan pembelajaran tatap muka di sekolah ataukah masih belum, sehingga diperlukan lagi pengembangan-pengembangan di dalam pelaksanaanya. Evaluasi paling sederhana dapat dilakukan dengan menganalisis motivasi belajar dan tanggapan atau respon siswa terhadap pembelajaran online. 
Motivasi atau minat belajar adalah hasrat atau daya yang mendorong seseorang untuk belajar (Hamdani, 2010). Siswa yang memiliki motivasi yang tinggi akan belajar dengan giat sehingga akan meningkatkan prestasi belajarnya. Begitu pula sebaliknya apabila siswa memiliki motivasi yang rendah maka cenderung malas untuk belajar sehingga prestasi belajarnya juga akan menurun. Eggen \& Kauchak (2012) menyatakan secara umum siswa yang termotivasi memiliki ciri-ciri sebagai berikut: (1) mengolah informasi secara mendalam dan cakap di dalam pengalaman belajar; (2) gigih dalam mengerjakan tugas-tugas yang sulit dan mengalamai lebih sedikit masalah-masalah manajemen; (3) memiliki sikap yang lebih positif terhadap sekolah dan menggambarkan sekolah sebagai sesuatu yang memuaskan. Motivasi siswa yang tinggi ataupun rendah dipengaruhi oleh faktor-faktor yang ada dalam diri siswa itu sendiri (internal) ataupun datang dari lingkungan (eksternal) (Legault, 2020). Faktor-faktor dalam diri siswa adalah minat terhadap bidang ilmu yang dipelajari serta kepeduliannya terhadap pendidikan. Adapun faktor-faktor yang datang dari lingkungannya seperti kualitas guru, metode pembelajaran, kondisi dan suasana kelas, serta sarana dan prasarana yang menunjang proses pembelajaran. Motivasi belajar pada diri siswa dapat ditingkatkan dengan cara mengoptimalkan faktorfaktor dari lingkungan seperti penggunaan metode pembelajaran yang menarik dan bervariasi, komunikasi yang dinamis antara guru dan siswa, serta ketersediaan sarana dan prasarana yang lengkap.

Penelitian-penelitian sebelumnya seperti yang dilakukan Arkorful (2014) dan Yodha et al., (2019) menunjukkan bahwa pembelajaran online memiliki kelebihan dan kekurangan dalam pelaksanaannya. Kelebihan dan kekurangan pembelajaran online tentunya berbeda antara suatu daerah dengan daerah yang lain yang disebabkan oleh perbedaan karakteristik daerah tersebut. Perbedaan karakteristik itu dapat berupa perbedaan sarana dan prasarana, model pembelajaran online yang digunakan, ataupun kemampuan IT siswa dan guru yang berbeda. Bisa saja di suatu daerah terdapat banyak kendala dan kekurangan dalam pelaksanaan pembelajaran online tetapi di daerah lain kendalanya tidak begitu besar. Besar kecilnya kendala dalam pelaksanaan pembelajaran online akan terlihat dari motivasi belajar siswa apakah meningkat ataukah menurun. Penelitian ini bertujuan untuk mengetahui kelebihan dan kekurangan pembelajaran online di SMA Wahidiyah Kediri di masa pandemi covid-19 yang diperoleh langsung dari respon siswa serta pengaruhnya terhadap motivasi belajar. Respon siswa diharapkan dapat memberikan gambaran terhadap kelebihan dan kekurangan dari pembelajaran online serta saran perbaikan yang perlu dilakukan. Kelebihan dan kendala dalam pelaksanaan pembelajaran online di SMA Wahidiyah Kediri di masa pandemi covid-19 bisa juga terjadi di sekolah ataupun daerah lain sehingga pengetahuan ini sangat penting sebagai upaya perbaikan. Respon siswa diharapkan dapat menjadi evaluasi terhadap pelaksanaan pembelajan online sehingga kedepannya dapat terlaksana dengan lebih baik. Pembelajaran online yang terlaksana dengan baik diharapkan juga dapat meningkatkan motivasi dan prestasi belajar siswa. Oleh sebab itu, judul yang diteliti adalah "motivasi belajar dan respon siswa terhadap online learning sebagai strategi pembelajaran di masa pandemi covid-19".

\section{METODE PENELITIAN}

Rancangan penelitian yang digunakan adalah deskriptif kuantitatif. Rancangan penelitian deskriptif bertujuan untuk mendeskripsikan dan menjelaskan objek atau sampel yang diteliti melalui data yang telah terkumpul sebagaimana adanya, tanpa melakukun analisis dan membuat kesimpulan yang berlaku umum (Sugiyono, 2012). Penelitian ini bertujuan untuk mengetahui motivasi belajar dan respon siswa terhadap pembelajaran online yang dilakukan di masa pandemi covid-19. Respon siswa berupa pernyataannya tentang kelebihan, kekurangan, dan saran perbaikan dalam pelaksanaan pembelajaran online. Populasi dalam penelitian ini adalah semua siswa SMA Wahidiyah Kediri yang berjumlah 710 orang. Sampel adalah responden yang dipilih yang mewakili populasi yang diteliti. Sampel dalam penelitian ini adalah $10 \%$ dari populasi yaitu 71 siswa yang dipilih secara acak (random sampling). 
Pengumpulan data dilakukan menggunkan instrumen pengukuran. Adapun instrumen pengukuran yang digunakan yaitu angket respon pembelajaran online (self-administered questionnaire), angket motivasi belajar, dan wawancara. Instrumen pengukuran berupa angket disebarkan secara online dengan metode survei menggunakan google formulir. Analisis data yang dilakukan bertujuan untuk memberi makna terhadap data yang telah dikumpulkan. Analisis data yang digunakan dalam penelitian ini yaitu analisis deskriptif. Data tentang motivasi belajar dan respon siswa terhadap pembelajaran online dianalisis secara deskriptif. Data ini dijabarkan pada tabel sehingga akan terlihat capaian siswa pada skor-skor tertentu.

\section{HASIL DAN PEMBAHASAN PENELITIAN}

Respon siswa terkait kelebihan dan kekurangan pembelajaran online di SMA Wahidiyah Kediri di masa pandemi covid-19 diperoleh menggunakan angket respon pembelajaran online (self-administered questionnaire). Angket ini dikembangkan oleh peneliti sendiri yang setiap pertanyaan atau pernyataanya sebagai gambaran keefektifan pembelajaran online yang dilakukan. Angket ini memiliki dua bentuk pertanyaan atau pernyataan yaitu berupa pilihan jawaban dan isian bebas. Bentuk pertama yang berupa pilihan jawaban siswa diminta untuk memilih antara sangat tidak setuju (STS), tidak setuju (TS), ragu-ragu (R), setuju (S), ataupun sangat setuju (SS) terkait penyataan-pernyataan pembelajaran online yang dilakukan. Bentuk pertama angket ini dapat dilihat pada pada Tabel 1.

Tabel 1 Respon Siswa terhadap Pembelajaran Online

\begin{tabular}{llllll}
\hline No & Pernyataan & \multicolumn{4}{c}{ Respon } \\
\cline { 3 - 6 } & STS & TS & R & S & SS \\
\hline 1 & $\begin{array}{l}\text { Sistem pembelajaran online sebaiknya dilaksanakan } \\
\text { seterusnya }\end{array}$ & $52 \%$ & $40 \%$ & $5 \%$ & $3 \%$ \\
\hline 2 & $\begin{array}{l}\text { Pembelajaran online dapat meningkatkan semangat } \\
\text { dan motivasi belajar }\end{array}$ & $20 \%$ & $76 \%$ & $4 \%$ & \\
\hline 3 & Pembelajaran online dapat meningkatkan hasil belajar & $8 \%$ & $80 \%$ & $12 \%$ & $4 \%$ \\
\hline 4 & $\begin{array}{l}\text { Tidak terdapat kendala/ kesulitan dalam pelaksanaan } \\
\text { pembelajaran online }\end{array}$ & $4 \%$ & $44 \%$ & $48 \%$ & $4 \%$ \\
\hline 5 & $\begin{array}{l}\text { Pembelajaran online memiliki banyak kelebihan dan } \\
\text { manfaat }\end{array}$ & $4 \%$ & $80 \%$ & $16 \%$ \\
\hline 6 & Pembelajaran online terlaksana secara efektif & $24 \%$ & $68 \%$ & $8 \%$ & \\
\hline
\end{tabular}

Berdasarkan Tabel 1 hanya 5\% siswa yang setuju dan 3\% siswa sangat setuju jika pembelajaran online dilaksanakan seterusnya. Artinya sebagian besar siswa ingin pembelajaran segera dilakukan secara tatap muka (face to face) di sekolah. Hal ini dipertegas dari sebagian besar siswa tidak setuju dan ragu-ragu pembelajaran online dapat meningkatkan motivasi dan hasil belajanya. Dari tabel juga terlihat jika pembelajaran online tidak terlaksana secara efektif dan memiliki banyak kekurangan atau kendala dalam pelaksanaannya. Hal ini dapat terjadi karena pihak-pihak terkait belum memiliki persiapan dengan baik sebelum pembelajaran online ini berlangsung. Permasalahan dan kendala siswa dalam pelaksanaan pembelajaran online tentunya dianalisis melaui respon atau tanggapan siswa itu sendiri. Dengan menganalisis respon siswa terhadap pembelajaran online maka akan diketahui sumber-sumber permasalahan yang sering kali terjadi dalam sistem pembelajaran ini sehingga dapat dicari solusi penyelesaiannya.

Bentuk kedua angket respon pembelajaran online (self-administered questionnaire) berupa isian bebas dimana siswa diminta untuk menjawab pertanyaan terkait kelebihan, kekurangan/ kendala, dan saran-saran perbaikan dalam pembelajaran online. Bentuk kedua angket ini dapat dilihat pada Tabel 2 di bawah ini.

Tabel 2 Kelebihan, Kekurangan, dan Saran Perbaikan terhadap Pembelajaran Online 
593 Motivasi Belajar dan Respon Siswa terhadap Online Learning sebagai Strategi Pembelajaran di Masa Pandemi Covid-19- Firmansyah

DOI: https://doi.org/10.31004/edukatif.v3i2.355

\begin{tabular}{|c|c|}
\hline Pertanyaan & Rangkuman Respon Siswa \\
\hline $\begin{array}{l}\text { Apakah kekurangan/ } \\
\text { kendala dalam } \\
\text { pelaksanaan } \\
\text { pembelajaran online? }\end{array}$ & 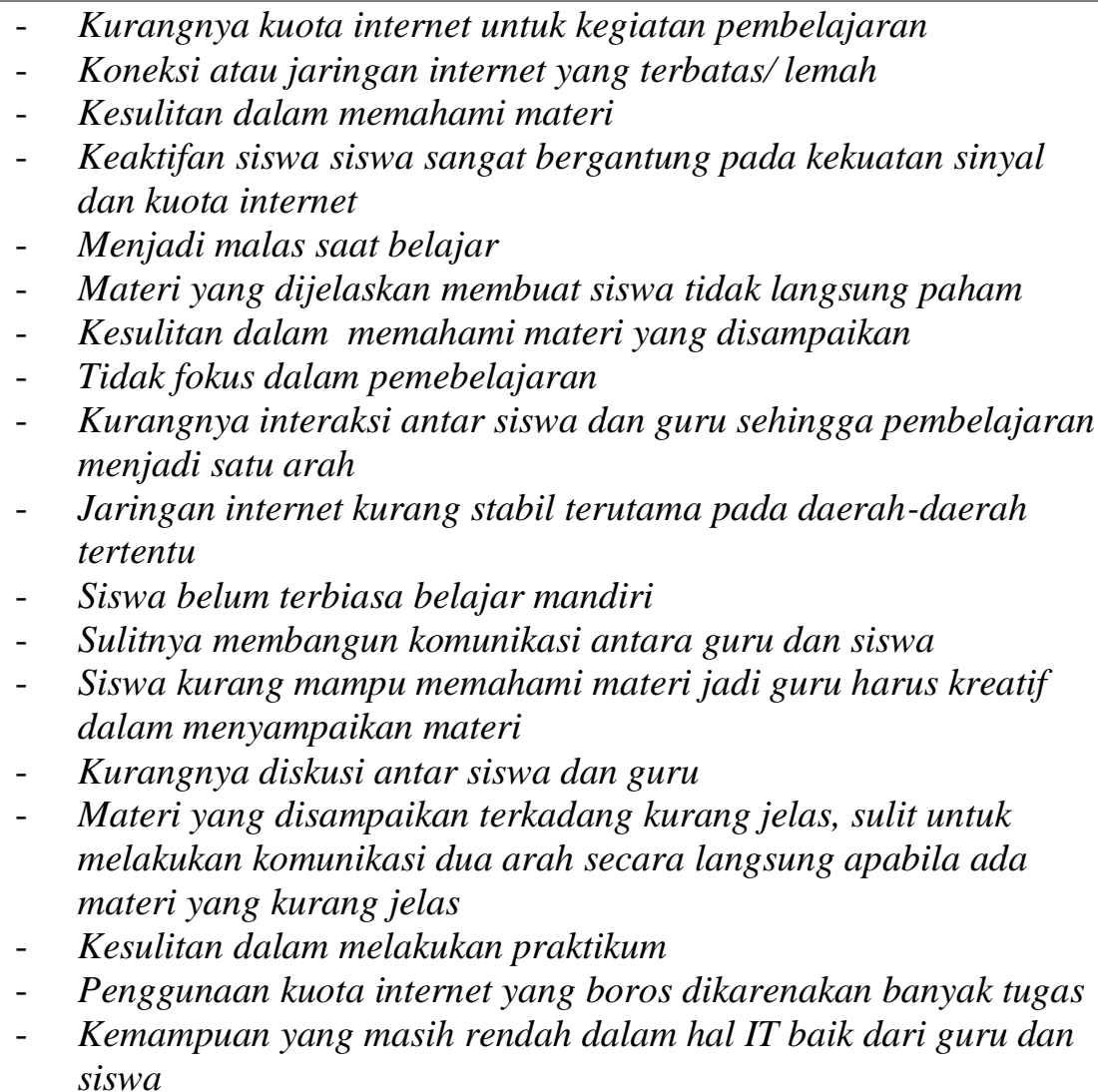 \\
\hline $\begin{array}{l}\text { Apakah kelebihan } \\
\text { dari pembelajaran } \\
\text { online? }\end{array}$ & 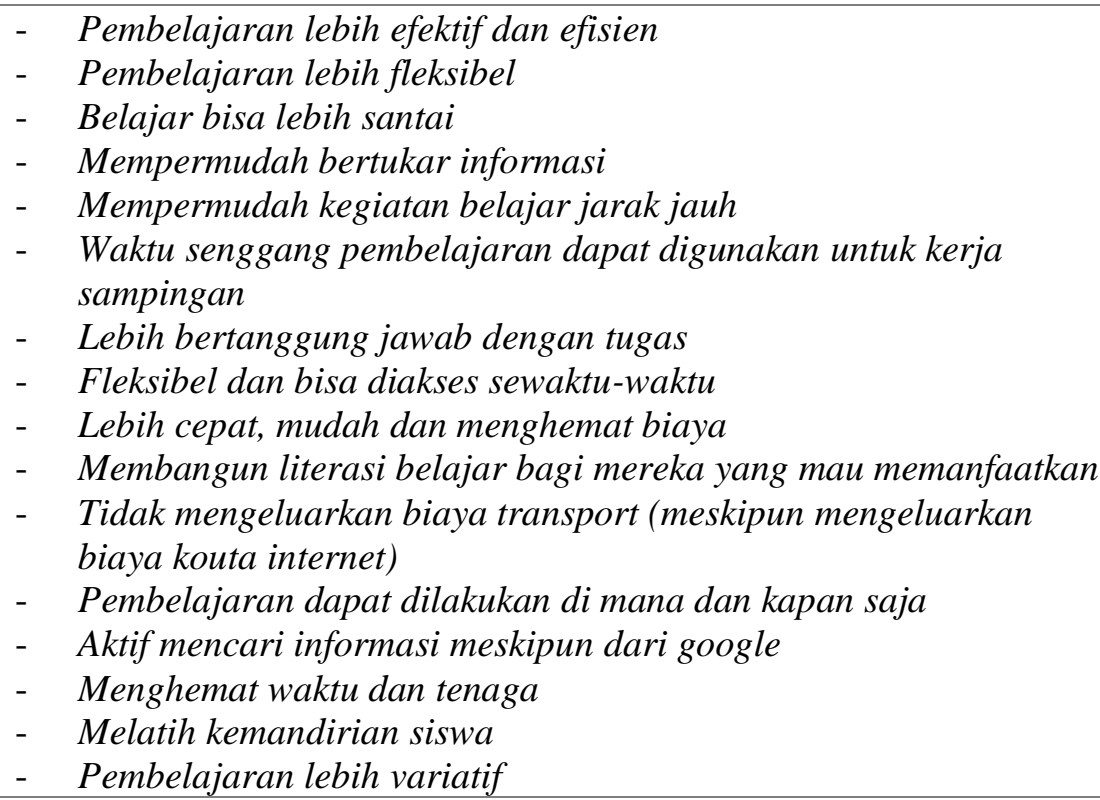 \\
\hline $\begin{array}{l}\text { Perbaikan apa yang } \\
\text { perlu dilakukan dalam } \\
\text { pembelajaran online? }\end{array}$ & $\begin{array}{ll}\text { - } & \text { Jaringan internet perlu diperbaiki } \\
\text { - } & \text { Kuota internet gratis yang lebih banyak dari pemerintah } \\
\text { - } & \text { Guru dan siswa harus lebih fokus dalam pembelajaran } \\
\text { - } & \text { Perbaikan dalam metode pembelajaran agar siswa mudah } \\
& \text { memaham materi } \\
\text { - } & \text { Kuota belajar disamaratakan } \\
\text { - } & \text { Guru diharap tidak cuek (acuh tak acuh) terhadap siswa yang } \\
& \text { kurang mampu memahami materi yang sedang dibahas } \\
\text { - } & \text { Pembelajaran harusnya bisa menjadi pendidikan karakter bagi }\end{array}$ \\
\hline
\end{tabular}




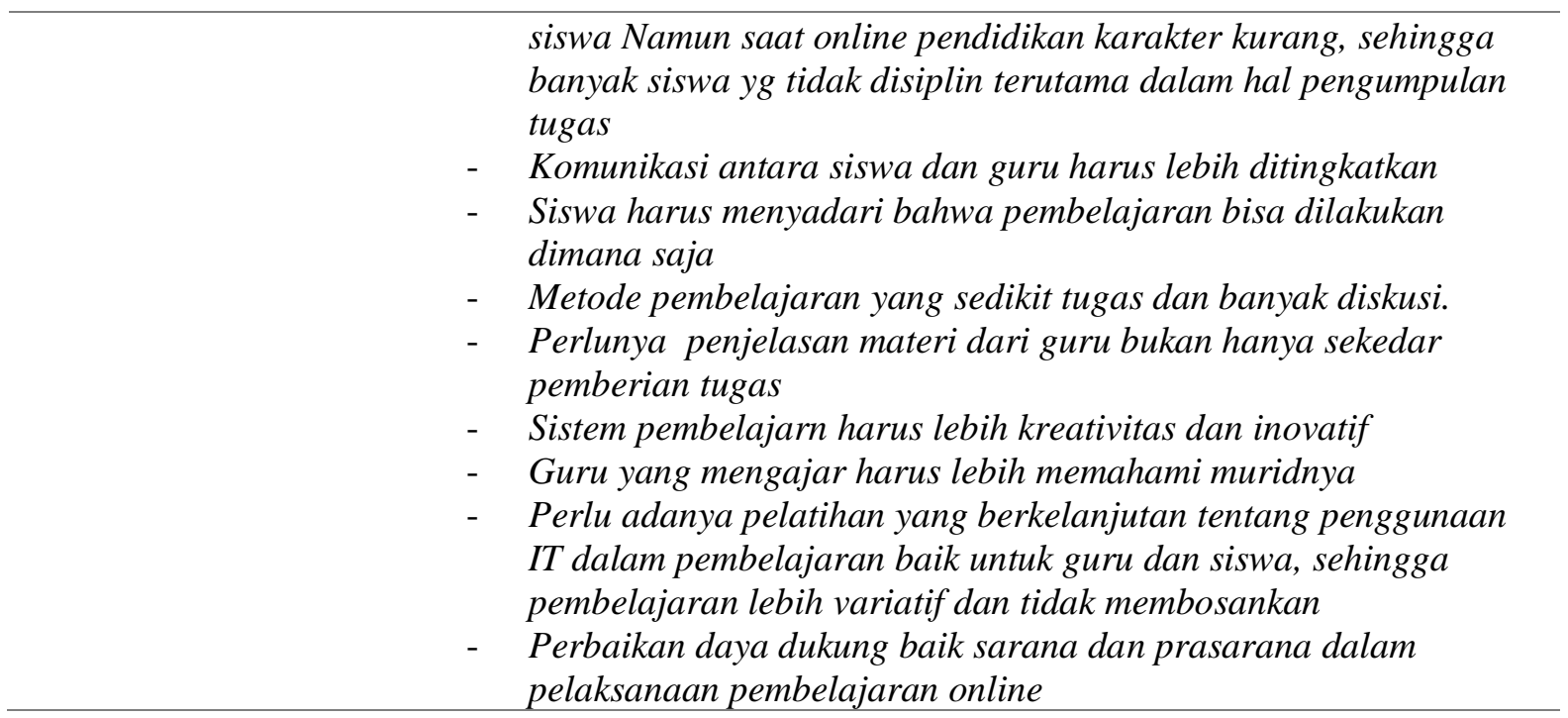

Berdasarkan Tabel 2 dari respon siswa dapat disimpulkan kelebihan dalam pembelajaran online yaitu: (1) pembelajaran dapat dilakukan dimana saja dan kapan saja; (2) melatih kemandirian belajar siswa; (3) pembelajaran lebih variatif; (4) sumber belajar yang lebih luas; dan (5) menghemat waktu, biaya, dan tenaga. Hal ini sesuai dengan pernyataan Gilbert et al., (2015) yang menyatakan siswa dapat belajar pada waktu dan tempat yang sesuai dengan kebutuhan belajar mereka. Siswa dengan menghemat waktu, biaya, dan tenaga akan lebih fokus dalam pembelajaran sehingga diharapkan prestasi belajarnya bisa meningkat. Adanya pembelajaran online ini juga membuat siswa lebih mandiri dan percaya diri karena pembelajaran yang lebih mengarah pada student centered sehingga mereka lebih berani dalam mengemukakan pendapat mereka (Nafrin \& Hudaidah, 2021). Kelebihan lainnya adalah sumber belajar yang banyak dan tidak terfokus pada buku pelajaran saja. Sumber belajar terebut yang dapat di akses melalui jaringan internet pada berbagai website baik berupa teks, gambar, ataupun video.

Sementara kendala dalam pelaksanaan pembelajaran online berdasarkan Tabel 2, yaitu: (1) koneksi atau jaringan internet yang lemah terutama pada daerah-dareah tertentu; (2) kebutuhan kuota internet yang besar; (3) kemampuan yang masih rendah dalam hal informasi dan teknologi (IT) baik dari guru maupun siswa; (4) model pembelajaran online yang belum tepat sehingga siswa kesulitan dalam memahami materi; dan (5) pendidikan yang kurang memperhatikan aspek afektif (sikap). Hal ini sesuai dengan penelitian Rozi et al., (2021) yang menyatakan akses sinyal internet menjadi kendala utama dalam pembelajaran online. Sinyal atau jaringan internet yang rendah akan menyebabkan terhambatnya interaksi antara guru dan siswa sehingga pembelajaran online tidak terlaksana dengan baik.

Adanya kendala dalam pelaksanaan pembelajaran online lebih disebabkan oleh kurangnya kesiapan dari pihak-pihak yang terlibat dalam sistem pembelajaran ini. Latar belakang siswa yang bervariasi juga dapat menjadi kendala dalam pembelajaran online seperti perbedaan kekuatan jaringan setiap daerah, ketersediaan kuota, dan kemampuan IT siswa yang berbeda. Guru juga belum mendesain suatu model pembelajaran online yang tepat sehingga siswa kurang termotivasi belajar dan kesulitan memahami materi yang disampaikan. Hal ini dikarenakan pemerintah memberi kebebasan guru membuat inovasi pembelajaran online dan tidak mengarahkan untuk menggunakan model pembelajaran tertentu. Keadaan ini membuat para guru masih mencoba mencari model pembelajaran online yang menarik dan dapat memotivasi siswa untuk belajar. Kesiapan dalam pelaksanaan pembelajaran online juga dapat dilakukan dengan pelatihan penggunaan IT ataupun merancang model pembelajaran online yang tepat. Menurut Lister (2014) ada 4 hal yang perlu diperhatikan dalam mendesain pembelajaran online, yaitu: (1) adanya kolaborasi dan interaksi antara guru dan siswa; (2) adanya umpan balik (feedback) dalam pembelajaran; (3) adanya materi pembelajaran; dan (4) 
urutan pembelajaran yang diinginkan. Sistem pembelajaran online dengan berbagai macam aplikasi belajar online yang ada sifatnya luas untuk dapat dapat dikembangkan. Pengembangan ini diperlukan agar diperoleh model pembelajaran yang menarik minat belajar serta siswa lebih mudah memahami materi.

Saran perbaikan secara umum menjadi solusi terhadap kendala dalam pelaksanaan pembelajaran online. Adapun saran perbaikan yang diperoleh dari respon siswa dapat disimpulkan, yaitu: (1) perbaikan daya dukung baik sarana dan prasarana dalam pelaksanaan pembelajaran online; (2) perbaikan dalam metode pembelajaran agar siswa mudah memaham materi; (3) pembelajaran harusnya bisa menjadi pendidikan karakter bagi siswa; dan (4) perlu adanya pelatihan yang berkelanjutan tentang penggunaan IT dalam pembelajaran baik untuk guru dan siswa, sehingga pembelajaran lebih variatif dan tidak membosankan. Persiapan pembelajaran dengan baik tentunya akan mengurangi kendala dalam pelaksanaan pembelajaran online. Yanuschik et al., (2015) juga menyampaikan hal-hal yang mempengaruhi kesuksesan pembelajaran online yaitu: (1) kemampuan siswa menggunakan komputer; (2) kepemilikan komputer pada siswa; dan (3) jaringan internet yang lancar.

Respon siswa berupa kelebihan dan kekurangan dalam pelaksanaan pembelajaran online di SMA Wahidiyah Kediri di masa pandemi covid-19 dilihat pengaruhnya terhadap motivasi belajar siswa apakah meningkat atau menurun. Deskripsi data motivasi belajar siswa diperoleh dari angket motivasi belajar model ARCS (attention, relenvace, confidence, satisfaction) yang diberikan kepada siswa terhadap pembelajaran online yang dilakukan. Persentase data motivasi belajar siswa dapat dilihat pada Tabel 3.

Tabel 3. Persentase Data Motivasi Belajar Siswa

\begin{tabular}{|c|c|c|c|c|}
\hline $\begin{array}{l}\text { Tidak } \\
\text { Termotivasi }\end{array}$ & Kurang & Cukup & Termotivasi & Sangat \\
\hline Termotivasi & Termotivasi & Termotivasi & & Termotivasi \\
\hline $0 \%$ & $21 \%$ & $70 \%$ & $9 \%$ & $0 \%$ \\
\hline
\end{tabular}

Berdasarkan Tabel 3 dapat diketahui bahwa siswa belum termotivasi mengikuti pembelajaran online, hal ini terlihat dari tingginya persentase pada kriteria kurang termotivasi yaitu $21 \%$ dan cukup termotivasi yaitu $70 \%$, sedangkan kriteria termotivasi hanya $9 \%$. Rendahnya motivasi belajar siswa dapat disebabkan oleh faktor dalam diri siswa itu sendiri (intrinsik) ataupun faktor dari luar atau lingkungan (ekstrinsik) (Filgona $e t$ al., 2020). Pada pembelajaran online faktor ekstrinsik yang dapat mempengaruhi motivasi belajar siswa adalah model pembelajaran online yang digunakan, aplikasi belajar online, dan kekuatan jaringan serta ketersediaan kuota internet (Maryam \& Emadi, 2014). Rendahnya motivasi belajar disebabkan oleh faktor-faktor ekstrinsik yang belum dapat memotivasi belajar siswa secara maksimal dikarenakan adanya kendala atau permasalahan dalam pelaksanaan pembelajaran online. Adapun kendala dalam pelaksanaan pembelajaran online yang diperoleh dari respon siswa yaitu: (1) koneksi atau jaringan internet yang lemah terutama pada daerah-dareah tertentu; (2) kebutuhan kuota internet yang besar; (3) kemampuan yang masih rendah dalam hal informasi dan teknologi (IT) baik dari guru maupun siswa; dan (4) model pembelajaran online yang belum tepat sehingga siswa kesulitan dalam memahami materi.

Deskripsi data motivasi belajar siswa juga dapat dilihat berdasarkan rata-rata skor motivasi setiap indikator. Rata-rata skor motivasi belajar siswa setiap indikator dapat dilihat pada Tabel 4.

Tabel 4 Rata-Rata Skor Motivasi Belajar Siswa Setiap Indikator

\begin{tabular}{lcc}
\hline \multirow{1}{*}{ Indikator } & & \\
\cline { 2 - 3 } & Rata-Rata Skor & Kriteria \\
\hline Attention & 3,00 & Cukup Termotivasi \\
\hline Relevance & 3,30 & Cukup Termotivasi \\
\hline Confidence & 3,15 & Cukup Termotivasi \\
\hline Satisfication & 3,25 & Cukup Termotivasi \\
\hline
\end{tabular}


Berdasarkan Tabel 4 dapat diketahui bahwa pada setiap indikator siswa juga belum termotivasi dalam mengikuti pembelajaran online. Pembelajaran online belum mendapat perhatian (attention) dengan baik oleh siswa. Relevansi antara materi pembelajaran dengan pengalaman belajar siswa belum terjalin secara maksimal. Hal ini mungkin terjadi karena adanya materi pelajaran yang sulit diajarkan secara online dan perlu dilakukan secara langsung di sekolah misalnya melakukan praktikum di laboratorium. Berdasarkan Tabel 4 juga menunjukkan bahwa rasa percaya diri dan kepuasan siswa dalam pembelajaran online belum maksimal. Rendahnya motivasi belajar siswa pembelajaran online di masa covid-19 ini dapat disebabkan oleh masih banyaknya kekurangan dan kendala dalam pelaksanaan pembelajaran. Menurut Tamm (2019) kekurangan dalam pembelajaran online, yaitu: (1) kurangnya kemampuan komunikasi siswa; (2) terbatasnya umpan balik (feedback) dalam pembelajaran; (3) pembelajaran lebih berfokus pada teori dari pada praktik; (4) membutuhkan motiasi diri yang kuat; (5) sistem penilaian yang tidak dapat dikontrol dengan baik; dan (6) keaktifan dan tingkat kepahaman materi siswa yang sulit dipantau oleh guru. Pembelajaran online agar terlaksana dengan baik membutuhkan motivasi diri siswa yang kuat karena guru tidak dapat mengontrol dan mengawasi siswa secara langsung.

Kekurangan dan kendala dalam pelaksanaan pembelajaran online di SMA Wahidiyah Kediri di masa pandemi covid-19 lebih mendomisai dibandingkan kelebihannya sehinga motivasi belajar siswa menjadi rendah. Kekurangan dan kendala dalam pelaksanaan pembelajaran online ini juga bisa terjadi di sekolah ataupun daerah lain sehingga pengetahuan ini sangat penting sebagai upaya antisipasi dan perbaikan. Respon siswa diharapkan dapat menjadi evaluasi terhadap pelaksanaan pembelajan online sehingga kedepannya dapat terlaksana dengan lebih baik.

\section{KESIMPULAN}

Respon siswa menunjukkan terdapat kelebihan dan kekurangan dalam pelaksanaan pembelajaran online di SMA Wahidiyah Kediri di masa pandemi covid-19. Kelebihan dalam pembelajaran online yang diperoleh dari respon siswa yaitu: (1) pembelajaran dapat dilakukan dimana saja dan kapan saja; (2) melatih kemandirian belajar siswa; (3) pembelajaran lebih variatif; (4) sumber belajar yang lebih luas; dan (5) menghemat waktu, biaya, dan tenaga. Adapun kendala dalam pelaksanaan pembelajaran online yaitu: (1) koneksi atau jaringan internet yang lemah terutama pada daerah-dareah tertentu; (2) kebutuhan kuota internet yang besar; (3) kemampuan yang masih rendah dalam hal informasi dan teknologi (IT) baik dari guru maupun siswa; dan (4) desain model pembelajaran online yang belum tepat sehingga siswa kesulitan dalam memahami materi. Kekurangan dan kendala dalam pelaksanaan pembelajaran online lebih mendominasi sehinga motivasi belajar siswa menjadi rendah.

\section{DAFTAR PUSTAKA}

Arkorful, V. (2014). The role of e-learning, the advantages and disadvantages of its adoption in Higher Education. In International Journal of Education and Research (Vol. 2, Issue 12). www.ijern.com

Dhull, I., \& Arora, S. (2017). Online learning. International Education \& Research Journal (IERJ), 3(8), 3234. https://doi.org/10.4324/9780429355097-7

Eggen, P., \& Kauchak, D. (2012). Strategi dan Model Pembelajaran. Terjemahan S. Wahono. Jakarta: PT. Index.

Fahy, P. J. (2007). Characteristics Of Interactive Online Earning Media. In Theory and Practice of Online Learning (Issue Chapter 7, pp. 167-199).

Filgona, J., Sakiyo, J., Gwany, D. M., \& Okoronka, A. U. (2020). Motivation in Learning. Asian Journal of Education and Social Studies, 10(4), 16-37. https://doi.org/10.9734/ajess/2020/v10i430273 
597 Motivasi Belajar dan Respon Siswa terhadap Online Learning sebagai Strategi Pembelajaran di Masa Pandemi Covid-19- Firmansyah

DOI: https://doi.org/10.31004/edukatif.v3i2.355

Gilbert, B., John, S., \& College, F. (2015). Online Learning Revealing the Benefits and Challenges. In Fisher Digital Publication. Paper 303.

Hamdani. (2010). Strategi Belajar Mengajar. Bandung. Pustaka Setia.

Keputusan Menteri Kesehatan Republik Indonesia No. 382 Tahun 2020 tentang Protokol Kesehatan Bagi Masyarakat di Tempat dan Fasilitas Umum dalam Rangka Pencegahan dan Pengendalian Corona Virus Disease 2019 (Covid-19). (2020).

Legault, L. (2020). Encyclopedia of Personality and Individual Differences. Encyclopedia of Personality and Individual Differences, November 2016, 1-5. https://doi.org/10.1007/978-3-319-28099-8

Lister, M. (2014). Trends in the Design of E-Learning and Online Learning. Journal of Online Learning \& Teaching, $\quad 10(4), \quad 671-680$. http://ezproxy.auckland.ac.nz/login?url=http://search.ebscohost.com/login.aspx?direct=true\&db=ehh\&A $\mathrm{N}=100728968 \&$ site $=$ ehost-live \&scope $=$ site

Maryam, T., \& Emadi, A. (2014). Study e-Learning ( Internet-based education ). Advances in Environmental Biology, 8(10), 901-906.

Nafrin, I. A., \& Hudaidah. (2021). EDUKATIF : JURNAL ILMU PENDIDIKAN Perkembangan Pendidikan Indonesia di Masa Pandemi Covid-19 Abstrak. 3(2), 456-462.

Oliver, M. (2000). Evaluating online teaching and learning. Information Services and Use, 20(2-3), 83-94. https://doi.org/10.3233/ISU-2000-202-304

Rozi, F., Putri, M. W., \& Wijaya, M. R. A. (2021). EDUKATIF : JURNAL ILMU PENDIDIKAN E-Learning System For Physical Education In IAIN Salatiga Using Google Classroom Abstrak. 3(2), 270-277.

Sugiyono. (2012). Metode Penelitian Pendidikan (Pendekatan Kualitatif, Kuantitatif dan R\&D). Bandung: Alfabeta.

Sun, A., \& Chen, X. (2016). Online education and its effective practice: A research review. Journal of Information Technology Education: Research, 15(2016), 157-190. https://doi.org/10.28945/3502

Yanuschik, O. V., Pakhomova, E. G., \& Batbold, K. (2015). E-learning as a Way to Improve the Quality of Educational for International Students. Procedia - Social and Behavioral Sciences, 215(June), 147-155. https://doi.org/10.1016/j.sbspro.2015.11.607

Yodha, A. S., Abidin, Z., \& Adi, P. E. (2019). PERSEPSI MAHASISWA TERHADAP PELAKSANAAN ELEARNING DALAM MATA KULIAH MANAJEMEN SISTEM INFORMASI MAHASISWA JURUSAN TEKNOLOGI PENDIDIKAN UNIVERSITAS NEGERI MALANG. Agustus, 2(3), 181187. http://journal2.um.ac.id/index.php/jktp/index 